\title{
Enteric Fever Diagnosis: Current Challenges and Future Directions
}

\author{
Durga P. Neupane, Hari P. Dulal and Jeongmin Song * (D) \\ Department of Microbiology and Immunology, Cornell University, Ithaca, NY 14853, USA; \\ dn332@cornell.edu (D.P.N.); hpd32@cornell.edu (H.P.D.) \\ * Correspondence: jeongmin.song@cornell.edu
}

check for updates

Citation: Neupane, D.P.; Dulal, H.P.; Song, J. Enteric Fever Diagnosis: Current Challenges and Future Directions. Pathogens 2021, 10, 410. https://doi.org/10.3390/ pathogens 10040410

Academic Editor:

Jaime Gómez-Laguna

Received: 3 March 2021

Accepted: 27 March 2021

Published: 1 April 2021

Publisher's Note: MDPI stays neutral with regard to jurisdictional claims in published maps and institutional affiliations.

Copyright: (c) 2021 by the authors. Licensee MDPI, Basel, Switzerland. This article is an open access article distributed under the terms and conditions of the Creative Commons Attribution (CC BY) license (https:// creativecommons.org/licenses/by/ $4.0 /)$.

\begin{abstract}
Enteric fever is a life-threatening systemic febrile disease caused by Salmonella enterica serovars Typhi and Paratyphi (S. Typhi and S. Paratyphi). Unfortunately, the burden of the disease remains high primarily due to the global spread of various drug-resistant Salmonella strains despite continuous advancement in the field. An accurate diagnosis is critical for effective control of the disease. However, enteric fever diagnosis based on clinical presentations is challenging due to overlapping symptoms with other febrile illnesses that are also prevalent in endemic areas. Current laboratory tests display suboptimal sensitivity and specificity, and no diagnostic methods are available for identifying asymptomatic carriers. Several research programs have employed systemic approaches to identify more specific biomarkers for early detection and asymptomatic carrier detection. This review discusses the pros and cons of currently available diagnostic tests for enteric fever, the advancement of research toward improved diagnostic tests, and the challenges of discovering new ideal biomarkers and tests.
\end{abstract}

Keywords: enteric fever diagnosis; typhoid fever diagnosis; Salmonella; Salmonella Typhi; enteric fever surveillance; antimicrobial resistance

\section{Introduction}

Enteric fever, referring to typhoid fever and paratyphoid fever, is a common bacterial disease with high morbidity and mortality rates in low- to middle-income countries in Asia, Africa, and South America, associated with limited proper sanitation and safe drinking water supply [1,2]. The World Health Organization (WHO) estimates up to 21 million enteric fever cases and 161,000 deaths each year worldwide. However, the actual burden of the disease is unknown since this estimate was extrapolated from the limited number of surveillance studies using current diagnostic measures [3]. Among over 2600 closelyrelated Salmonella enterica serovars, human-restricted Salmonella enterica serovars Typhi and Paratyphi A, B, and C (S. Typhi and S. Paratyphi A, B, and C) are the cause of enteric fever. Different Salmonella serovars, including $S$. Typhi and $S$. Paratyphi, are characterized by a distinct set of their surface antigens: lipopolysaccharide $\mathrm{O}$ (somatic), flagellar $\mathrm{H}$, and virulence-capsule (Vi) antigens [4]. Based on their host-specificity and disease outcomes, S. enterica are grouped into typhoidal and nontyphoidal Salmonella serovars (NTS). The majority of NTS serovars represented by $S$. Typhimurium and $S$. Enteritidis can infect humans and animals and cause a self-limiting gastrointestinal Salmonellosis in humans, with some exceptions of NTS causing invasive disease [5-7].

In addition to diagnostic challenges associated with closely related Salmonella serovars, the infection route and some clinical presentations are also shared among Salmonella serovars. Salmonella serovars are transmitted through the fecal-oral route after the ingestion of contaminated food and water. The incubation period of enteric fever is approximately 8-14 days [8], while the duration and severity of the disease are affected by the types of bacterial strains and doses as well as host immune responses [9-11]. Typhoid and paratyphoid fevers are clinically indistinguishable from each other. They can present with comparable severity of the complications, although typhoid fever is more prevalent than paratyphoid 
fever in most endemic areas [12,13]. For instance, clinical presentations such as high fever, headache, malaise, anorexia, rapid pulse, leukopenia, thrombocytopenia, abdominal discomfort, and neurological complications are not specific to enteric fever [14,15], making a clinical-presentation-based diagnosis difficult. Viral (e.g., dengue, influenza), parasitic (e.g., malaria, typhus, leishmaniosis), and other bacterial (e.g., brucellosis, tuberculosis) infections that are also common in endemic areas may develop similar symptoms [16]. The current diagnostic tests cannot reliably distinguish enteric fever from others.

The global spread of multidrug-resistant (MDR) Salmonella and the emergence of extensively drug-resistant (XDR) Salmonella also support the need for improved diagnostic tests, as well as new treatment strategies that are alternatives to current antibiotics. Antibiotics are primary treatment options for enteric fever, but Salmonella is continuously evolving to acquire plasmid, prophage, transposon, or chromosomal gene mutations to attain antibioticresistance. A myriad of reports has indicated the global spread of $S$. Typhi and $S$. Paratyphi strains that are resistant to all of the first-line antibiotics, ampicillin, chloramphenicol, and co-trimoxazole, collectively known as multidrug-resistance (MDR) Salmonella [17-19]. All of the identified MDR $S$. Typhi and $S$. Paratyphi carry the IncHI1 plasmid, while other antibiotic-resistant related genes found in MDR Salmonella can vary [20]. Haplotype-58 (H58) is the most dominant MDR S. Typhi strain identified in various parts of Asia and Africa and travel-related MDR cases in other countries [21-25].

The emergence and spread of Salmonella strains resistant to the second line of drugs have also been reported [25,26]. Resistance to fluoroquinolones has been acquired by chromosomal mutations in the quinolone resistance gene $q n r S$ and/or quinolone resistance determining region (QRDR) harboring gyr $A, g y r B$, parC, and parE genes [25,26]. Resistance to third-generation cephalosporins is associated with the acquisition of several extended-spectrum $\beta$-lactamase (ESBL) genes [27]. The XDR H58 S. Typhi strain, resistant to ampicillin, chloramphenicol, co-trimoxazole, fluoroquinolones, and third-generation cephalosporins, was first identified in Pakistan, affecting over 300 cases in 2016 [27]. Since then, XDR $S$. Typhi infection remains prevalent in the region, and travel-related XDR $S$. Typhi infections have been reported in many other countries [28-31], indicating the rapid global spread of XDR S. Typhi. XDR H58 isolates harbored the IncY plasmid, carrying an ESBL-resistance gene. Azithromycin and carbapenems are "last resort" antibiotics for treating Salmonella infection, but the emergence of azithromycin-resistant $S$. Typhi strains and carbapenem-resistant invasive NTS has also been reported [32-35]. These observations support the urgent need of improved diagnostic, prevention, and treatment strategies to better control drug-resistant $S$. Typhi and $S$. Paratyphi.

Ideal diagnostic tests should also detect asymptomatic carriers and distinguish the infection from others. A significant population $(2-5 \%)$ of recovered patients become asymptomatic chronic carriers who can shed the bacteria intermittently in their feces for years [36,37]. Chronic carriers serve as a primary reservoir of $S$. Typhi and $S$. Paratyphi that persist mainly in the gallbladder for local and global spread [37-39], as they are human-restricted pathogens with no other known reservoirs.

The arrival of new diagnostic tests allowing the early detection of $S$. Typhi and $S$. Paratyphi infection and the detection of chronic carriers would help eradicate enteric fever. This review discusses the pros and cons of the currently available diagnostic tests for enteric fever, notable bacterial virulence factors in the context of their potential to be used as new diagnostic biomarkers, other bacterial determinants identified by systemic approaches as promising biomarkers, and the remaining challenges of discovering new ideal biomarkers and tests.

\section{Current Enteric Fever Diagnostics}

Laboratory diagnosis is required to confirm enteric fever. Although enteric fever has been well established for more than a century, there has not been a single "ideal" laboratory diagnostic biomarker available (Table 1). 
Table 1. Diagnostic tests for acute enteric-fever-suspected patients (fever $\geq 38^{\circ} \mathrm{C}$ for $\geq 3$ days).

\begin{tabular}{l} 
Methods \\
\hline \multicolumn{1}{c}{ Mlood/bone marrow } \\
culture \\
(confirmed by \\
positive culture results)
\end{tabular}

a. $100 \%$ specificity.

b. Isolated bacteria can also be used for subsequent antibiotic susceptibility tests and molecular characterization.

\begin{abstract}
a. Low sensitivity: $\sim 50 \%$ blood culture, $\sim 80 \%$ bone marrow culture.

b. Bone marrow collection is invasive.

c. Time-consuming ( $\geq 48 \mathrm{~h}$ ).

d. These test methods require

trained personnel and

infrastructure, which are not necessarily common in endemic areas.
\end{abstract}

Adjustments *

a. Use of larger sample volume. b. Lowering bactericidal activity of blood (by supplementing bile salt or sodium polyethanol sulfonate, removing serum, or diluting blood).

c. Lysis of blood cells to release bacteria. a. Bile/stool positive can also be due to chronic infection. b. Test methods show moderate sensitivity and specificity. c. Time-consuming ( $\geq 48 \mathrm{~h}$ ). d. These test methods require trained personnel and infrastructure, which are not necessarily common in endemic areas.

a. Nucleic acid tests can also

Bacterial nucleic acid detection (suggested by positive results)

Bile/stool culture (suggested by positive results) used for subsequent antibiotic susceptibility tests and molecular characterization. a. Nucleic acid tests can also
detect non-culturable/dead

bacteria (beneficial for

patients who already take antibiotics

a. Moderate sensitivity and specificity. a. Use of larger sample volume. before office visits).

a. Quick turnaround time associated with high point-of-care compatibility. b. Some serological tests are simple, quick, and inexpensive.
Serological tests (suggested by positive results)

* Test success rates can be improved by adjustments.

\begin{abstract}
a. Cross-reactivity.
b. Moderate sensitivity and specificity.
\end{abstract}

a. Bacterial nucleic acids can be enriched by removing human DNA and transient culture.

\subsection{Bacterial-Culture-Based Diagnosis}

The definitive diagnosis of enteric fever requires the isolation of bacteria from blood or bone marrow, accompanied by fever $\geq 38^{\circ} \mathrm{C}$ for at least three days [40]. Culture remains the mainstay of diagnosis, and bacterial isolation allows us to characterize the pathogen for antibiotic resistance genes and the causation of the outbreak of disease in the particular location. Although the method has $100 \%$ specificity, it lacks sensitivity. On average, blood and bone marrow cultures have a sensitivity of $\sim 50 \%$ and $\sim 80 \%$, respectively, which directly correlates with the number of viable bacteria in blood $(\leq 1 \mathrm{CFU} / \mathrm{mL})$ and bone marrow ( 10 CFU/mL) [41,42]. Various strategies have been employed to increase the sensitivity of bacterial-culture-mediated diagnosis (Table 1). For example, supplementation of ox bile or bile salt (sodium taurocholate) to the culture media has resulted in increased bacterial isolation frequency in a shorter time [43]. More specifically, bile contents suppress the bactericidal activity of blood and lyse blood cells to release bacteria.

Similarly, sodium polyethanol sulfonate can also reduce the bactericidal activity of blood [44] and shorten the testing time required for bacteria isolation without changing the overall isolation frequency [45]. After removing serum due to its bactericidal activity, blood clot culture also exhibits increased sensitivity and rapid bacterial growth [46-48]. More blood volumes and additional dilutions of the specimens with media have also been 
used to improve bacterial detection frequency and address the sensitivity issue associated with culture-based diagnosis methods [49].

These studies indicate that the optimum ratio of blood to bacterial culture media (e.g., tryptic soy broth (TSB)) should be 1:10 or greater. The standard method involves an incubation at $37^{\circ} \mathrm{C}$ and an inspection for bacterial growth for at least a week. In general, positive cultures are subcultured at $37^{\circ} \mathrm{C}$ for $24 \mathrm{~h}$ on both nonselective enriched media (e.g., blood agar) that supports the growth of most bacteria and selective differential media (e.g., MacConkey agar, xylose lysine deoxycholate (XLD) agar) that allows the growth of biletolerant bacteria such as $S$. Typhi and $S$. Paratyphi for diagnosis. The use of nonselective media such as TSB or blood agar helps isolate bacterial pathogens in blood, which should be sterile in healthy individuals. The use of selective media such as MacConkey and XLD agars helps differentiate non-lactose-fermenting bacteria such as $S$. Typhi and $S$. Paratyphi from lactose-fermenting bacteria such as E. coli and bile-tolerant S. Typhi and $S$. Paratyphi from other pathogens such as Gram-positive bacteria and E. coli, respectively. Biochemical identification and agglutination with specific antisera tests are followed to diagnose infection with $S$. Typhi and/or $S$. Paratyphi. The basis of serotyping is described in the latter part of this paper (Section 2.3).

There are some additional challenges associated with blood-culture-based diagnostic methods. In brief, compared to the use of 5-10 mL blood samples for school-age children and adults during the first two weeks of the infection, at which the bacterial load is higher $[41,50]$, a smaller blood volume $(2-4 \mathrm{~mL})$ is used for preschool children [40], which is likely associated with underdiagnosis among younger populations [51]. Prior antibiotic therapy, which remains very common in endemic areas, also hinders culture-based diagnosis $[52,53]$. This challenge is overcome by using bone marrow samples rather than blood for bacterial culture since bacteria in the bone marrow are unlikely cleared by antibiotic treatment $[52,54]$. For this reason, bone marrow culture is generally considered the gold standard for enteric fever diagnosis in endemic areas. However, this method involves an invasive procedure for sample collection and requires specialized skills and equipment to conduct.

Besides bacterial isolation from blood and bone marrow samples, in some cases, other biological samples such as rose spot, duodenal bile, stool, and urine are used for Salmonella isolations via culture. A rose spot culture gives $\sim 60 \%$ sensitivity, which is a noninvasive procedure, but the occurrence of these spots is relatively rare among enteric fever patients (1-30\%) [42]. Duodenal aspirate culture can provide a better diagnostic value than stool culture, but the test's tolerance, particularly among children, hampers its use [55]. The positive results from these other biological samples are only suggestive of active disease due to chronic carriage prevalence in endemic areas. Therefore, a positive result should be interpreted in combination with other assays.

As described above, a bacterial-culture-based diagnosis is the gold-standard for enteric fever diagnosis, also allowing for antibiotic-susceptibility testing that is essential for determining a proper antibiotic treatment strategy. The primary challenges of this method include a slower turnaround time $(\geq 48 \mathrm{~h}$ ) required for bacterial growth and identification and the need for appropriate laboratory infrastructure, which is not necessarily common in endemic areas.

\subsection{Bacterial Nucleic Acid Detection-Based Diagnosis}

Nucleic acid detection involves polymerase chain reaction (PCR) that amplifies Salmonella serovar-specific DNA for diagnosis. The primary advantage of this method is the rapid turnaround time. PCR methods are advantageous because they can detect Salmonella-specific DNA extracted from live or dead bacteria or both. Dead bacteria in blood can result from antibiotic treatments, which is also common in some endemic areas and/or outcomes of host immune responses. The disadvantage of PCR methods includes the need for trained personnel and special equipment to conduct the PCR. 
This method involves DNA extraction from patient samples followed by amplification of Salmonella-specific DNA sequences. The most commonly used target genes for enteric fever diagnosis include flagellin $(f l i C)$, Vi polysaccharide (viaB), 16s rRNA, heat-shock protein (groEL), cytotoxin $(\operatorname{cly} A)$, and other conserved genes. Due to the lack of a standard reference method, the accuracy of the test is generally calculated based on blood culture results. Various studies have demonstrated that the sensitivity ranges from $40-100 \%$, as shown by different studies, while the specificity can be near $100 \%$ if conducted under optimal conditions [56-64].

Various platforms, from conventional PCR to quantitative real-time PCR (qRT-PCR), nested PCR, multiplex PCR, and loop-mediated isothermal amplification (LAMP) PCR, have been reported to demonstrate variable sensitivity. Still, none of them are free from limitations. Removal of background human DNA from blood specimens [65] and a brief culture of blood samples before the PCR reaction (dubbed blood culture PCR [66]) showed an increased sensitivity by several folds. In summary, PCR-based methods are relatively simpler, faster, and more cost-effective than their culture-based counterparts. However, disease detection sensitivity remains an issue to serving as an optimal assay.

\subsection{Serological Diagnosis}

Serological identification of S. enterica serovars relies on Kauffman-White classification. Currently available serological tests cannot reliably diagnose enteric fever (specificity is not $100 \%$ ) as many of the antigens are shared among different Salmonella serovars. The major antigens used to differentiate $S$. Typhi and $S$. Paratyphi are often restricted to Vi, lipopolysaccharides (LPS) $\mathrm{O}$, and flagellar $\mathrm{H}$ antigens, yet some of the antigens are shared among different Salmonella serovars (Table 2). Therefore, unlike blood-culture-mediated diagnostic methods, positive results from serological diagnostic tests are suggestive of enteric fever (Tables 1 and 2). However, serological tests are simple and quick, which is highly valuable for managing disease in impoverished endemic areas in a timely manner.

Table 2. Serological identification of Salmonella.

\begin{tabular}{ccccc}
\hline Serovar Name & LPS O Ag & Flagella H Ag & Vi Ag * & \multicolumn{1}{c}{ Cross-Reactivity } \\
\hline S. Typhi & 9 & d & Positive & $\begin{array}{l}\text { O9 Ag is present in S. Enteritidis, } \\
\text { S. Dublin, and S. Gallinarum. } \\
\text { Vi Ag is present in S. Paratyphi C, } \\
\text { S. Dublin, and Citrobacter freundii. }\end{array}$ \\
\hline S. Paratyphi A & 2 & a & Negative & \\
\hline S. Paratyphi B & 4 & b & Negative & O4 Ag is present in S. Typhimurium. \\
\hline S. Paratyphi C & $6 / 7$ & c & Positive & $\begin{array}{l}\text { O6/7 Ags are present in S. Choleraesuis. } \\
\text { Vi Ag is present in S. Dublin, Citrobacter } \\
\text { freundii, and S. Typhi. }\end{array}$ \\
\hline
\end{tabular}

* Vi antigen is mainly used to screen for chronic carriers [67].

$\mathrm{Vi}$ antigen is a linear polymer of $\alpha-1,4-2-\mathrm{deoxy}-2-\mathrm{N}$-acetylgalacturonic acid [68]. The genes involved in the expression regulation ( $t v i A)$, synthesis ( $t v i B C D E)$, and transport and localization (vex $A B C D E$ ) of $\mathrm{Vi}$ polysaccharide are located in the viaB locus as part of Salmonella Pathogenicity Island 7 (SPI 7) [69]. The synthesis of Vi polysaccharides is also regulated by a global regulator system $\operatorname{rcs} A B C$ located in the viaA locus [70]. Vi polysaccharides are exclusively present in $S$. Typhi and $S$. Paratyphi $C$ (as well as $S$. Dublin and Citrobacter freundii) while absent from S. Paratyphi A and B and NTS [71]. Vi-antigenbased agglutinations have two major limitations, associated with the recent emergence of Vi-negative strains of $S$. Typhi [72] and the requirement of certain environmental cues for Vi antigens to be expressed by Vi-positive $S$. Typhi strains (e.g., higher osmolality) [73,74].

Somatic O-antigen, a portion of LPS, is present on the outer surface of Gram-negative bacteria. Salmonella strains fall into $46 \mathrm{O}$ serogroups that differ in types of sugars, their 
arrangements, and the linkage within and between repeated $\mathrm{O}$-antigen units, contributing to one of the most variable cell constituents, encoded by highly polymorphic $r f b$ genes [75], thus providing the basis for serotyping schemes $[76,77]$. Vi antigen expressed on the bacterial cell surface can interfere with $\mathrm{O}$-antigen-mediated agglutination, which can be overcome by boiling the bacteria culture for $10 \mathrm{~min}$, a procedure that removes heat-labile Vi but not heat-stable O-antigen [78].

Flagella are present on the cell surface of some bacteria, which facilitate bacterial locomotion. Flagellin protein is the main component of the extracellular flagellar filament that is expressed by one of two genes, $\mathrm{H} 1$ ( fliC) and $\mathrm{H} 2$ ( $f l j B)$, one at a time, in Salmonella, known as phase variation [79]. The major types of flagellar H-antigens present in typhoidal Salmonella are shown in Table 2. S. Typhi primarily consists of monophasic H:d antigen; however other variants, H:j or H:z66, have also been reported [80,81].

The most commonly used serological assay in the endemic setting is the Widal test, which measures the agglutination of bacterial $\mathrm{O}$ and $\mathrm{H}$ antigens with antisera specific for these antigens $[82,83]$. This test should be performed twice to improve test accuracy: once during the acute phase and the other during the convalescent phase of the infection, which can be approximately 10 days apart. The test result is considered positive if there is a four-fold increase in antibody titers between the two tests [84]. However, due to the unique circumstances posed in endemic areas, a single Widal test is widely used in the field, especially during the early phase of acute infection $[85,86]$. The interpretation of a single Widal test is complicated by various background antibodies in people of different endemic areas, necessitating determining the cutoff values of antibodies level for determining a positive result [87]. Therefore, when optimum cutoff values tailored for the particular endemic regions are implemented, the specificity and sensitivity of the Widal test can be significantly improved and is better than most of the available rapid diagnostic tests (RDTs) such as Tubex and Typhidot [88]. However, caution should be taken as some other bacteria, as listed above, also express $\mathrm{O}$ - and/or H-antigens, which can result in false-positive results [89].

Several RDTs evaluating the presence of enteric-fever-specific immunodominant antigens have been developed to meet the speedy diagnosis requirement in endemic areas [90]. The most commonly used RDTs are Tubex and Typhidot. Tubex detects anti-O9 IgM antibodies in S. Typhi [91] and anti-O2 antibodies in S. Paratyphi [92]. Typhidot detects IgM and IgG antibodies against the 50-kDa outer membrane protein of S. Typhi [93,94]. IgM detection is the most suitable marker for diagnosing acute infection among people who have not previously been infected with $S$. Typhi and $S$. Paratyphi and have not been vaccinated with the Ty21a live attenuated vaccine. IgG detection suggests reinfection in convalescent patients, infection in vaccinated people, or asymptomatic carriers. These tests showed $80-90 \%$ specificity and $70-80 \%$ sensitivity [90], supporting a possibility of more extensive use of these tests in clinical diagnostic laboratories in endemic regions where a rapid point-of-care (POC)-compatible test is desired for timely management of the disease.

\section{Future Directions for New Diagnostic Development}

Advancing our understanding of host-pathogen interactions, with an emphasis on the bacterial antigens involved, and host responses against the pathogens during various stages of infection will help us discover a diagnostic biomarker(s) suitable for new diagnostic methods, with higher specificity and sensitivity tailored for patient circumstances associated with vaccination and past-infection history.

\subsection{Overview of Host-Pathogen Interactions}

The genome size of $S$. Typhi is approximately $4.8 \mathrm{Mb}$, producing around 4700 proteins, almost $90 \%$ of which are highly shared with NTS, such as $S$. Typhimurium [95-98]. The $S$. Typhi specific genome consists of 300-400 genes and is characterized by an accumulation of around 200 pseudogenes, also shared in the $S$. Paratyphi genome $[95,99,100]$. Some of these pseudogenes have functional homologs in NTS serovars that have roles in intestinal 
colonization. This may partly explain why typhoidal Salmonella favors systemic sites in contrast to NTS [101]. Different pathogenic Salmonella strains have evolved by acquiring virulence genes located in the loci called Salmonella pathogenicity islands (SPIs), prophages, and plasmids [102-104]. Various SPIs of varying sizes have been identified, and they encode a cluster of virulence factors that have a role in adhesion, invasion, survival, and toxin production. For example, SPI-1 and SPI-2 encode the type III secretory systems (T3SSs) and many effector proteins. SPI-1 has a role in the invasion of bacteria into intestinal epithelial cells, while SPI-2 is essential for the survival and replication of bacteria within phagocytes. While many SPIs are shared between typhoidal Salmonella and NTS, S. Typhi has four relatively unique SPIs: SPI-7, 8, 15, and 18 [96]. S. Typhi encodes relatively unique virulence factors, such as the virulence (Vi) capsule [71] and a type IVb pilus [105] encoded by SPI-7, the largest SPI, hemolysin (HlyE) encoded by SPI-18 [106], and the typhoid toxin [107,108], among others.

Following ingestion, Salmonella can adhere to the mucosa in the small intestine and invade epithelial cells or be taken up by microfold (M) cells [109]. Bacteria enter M cells through receptor-mediated endocytosis and other epithelial cells through an SPI1-mediated process [110,111]. Postinvasion, bacteria released from intestinal cells are engulfed by phagocytes, primarily by tissue macrophages in the lamina propria. Despite bactericidal activities triggered by host cells, $S$. Typhi can survive and replicate in macrophages by employing SPI-2 virulence factors. Some macrophages then enter the bloodstream through the lymphatic system. This process can result in transient bacteremia, followed by the dissemination of bacteria to the reticuloendothelial system involving the liver, spleen, bone marrow, and gallbladder, all of which can happen within $24 \mathrm{~h}$ of pathogen ingestion [40]. During the incubation period, the bacteria markedly replicate in these organs; in some cases, they shed back into the bloodstream, causing secondary bacteremia, which is usually associated with enteric fever symptoms, although bacteria numbers in blood are generally low [112].

Typhoidal Salmonella can induce mucosal, humoral, and cell-mediated immune responses in the host $[113,114]$. The bacteria contain specific pathogen-associated molecular patterns that are recognized by the host innate immunity components, such as Toll-like receptor (TLR) and NOD-like receptor (NLR), on different cell types [115]. For example, flagellin, a protein component of bacterial flagella, is recognized by TLR5 [116], while bacterial DNA can activate TLR9 [117]. The lipid A and lipoprotein moieties of lipopolysaccharide (LPS) stimulate TLR4 and TLR2, respectively $[118,119]$. Similarly, type IVb pilus has a role in the invasion of human cells [120]. In the case of noninvasive NTS, these interactions lead to the activation of proinflammatory responses localized in the intestine, with the consequence of rapid onset of diarrhea within 12-72 h. However, typhoidal salmonellae typically do not trigger a proinflammatory response [121], where Vi CPS and the typhoid toxin play a role in inhibiting host immune responses by hindering the PAMPs, such as LPS O-antigen, and altering recruited immune cell function and/or depleting those cells, respectively $[108,118,122-124]$. The absence of profound inflammatory responses in infection with typhoidal Salmonella is also likely associated with only a transient presence in the circulation while maintaining its intracellular lifecycle in the reticuloendothelial system for most of its infectious cycle $[118,125]$. In S. Paratyphi A, which does not encode the genes for Vi CPS, a very long O-antigen plays a similar role to Vi CPS of $S$. Typhi, which helps evade host innate and adaptive immune responses [126].

\subsection{Emerging Diagnostic Methods}

New biomarker discovery efforts based on proteomics, transcriptomics, and metabolo mics have been among the most widely investigated approaches, which is discussed in this section. Using these approaches, investigators have sought biomarkers specific to acute enteric fever patients, allowing them to differentiate these patients from other infectious disease patients and healthy individuals. There are numerous challenges associated with discovering ideal enteric fever biomarkers, which include rather less straightforward vali- 
dation methods stemming from the lack of a reference standard. Since no single current diagnostic method is perfect, a composite reference standard (CRS) that combines multiple diagnostic tests has been proposed to overcome such limitations [127]. Alternatively, a computational model using Bayesian probability has also been proposed to estimate the accuracy of enteric fever diagnostic tests [128-131]. Such approaches have revealed a better coverage of actual patients, indicating a promise of these methods based on estimated higher specificity and sensitivity. Furthermore, a lack of an animal model recapitulating the entire infectious life cycle of typhoidal Salmonellae has hampered researchers in understanding the pathogenic mechanism and, thus, exploring novel biomarkers. Still, additional efforts are needed to find an ideal biomarker(s) that is expressed early in the infection stage, indicates drug-resistance profiles, and clearly distinguishes acute infection from subclinical infections or chronic carriers that are prevalent in endemic areas.

\subsubsection{Protein Biomarkers}

High-throughput approaches, such as conventional and modified proteomics and immunoscreening, have been used to discover immunodominant antigen signatures associated with enteric fever, for instance, protein microarrays, where the whole proteome of Salmonella expressed in E. coli was probed with enteric fever patient samples to screen for the presence of specific immunodominant bacterial antigen signatures [132-134], and immunoaffinity proteomics-based technology (IPT), where columns were packed with enteric fever patient antibodies and probed with bacterial antigens to discover bacterial antigens highly immunogenic in enteric fever patients [135]. Mass spectrometry-based proteomics was followed to identify the bound bacterial proteins.

Studies using liquid chromatography-mass spectrometry (LC-MS) have identified several hundred Salmonella antigens; some of them have been further demonstrated using more conventional approaches such as Western blotting for their differential diagnostic potential of acute enteric fever [136]. Some immunogenic bacterial antigens discovered from these studies are outer membrane proteins OmpA and OmpC; virulence factors PagC, $\mathrm{CdtB}$, PltA, and HlyE; chaperone GroEL; locomotor protein flagellin; fimbrial subunits SthA and SthD; LPS, among others. Some of these potential biomarkers include typhoidal Salmonella proteins such as CdtB, PltA, and HlyE. Intracellular pathogens like $S$. Typhi and $S$. Paratyphi dynamically change their gene expressions during infection, which are drastically different from the ones expressed during in vitro laboratory culture conditions (e.g., LB). Consistently, many $S$. Typhi genes are known to be exclusively expressed from intracellularly located bacteria (e.g., CdtB, PltA, PltB, HlyE, and SPI effector proteins) $[107,137,138]$. To better reflect bacterial antigens expressed during human infection, in-vivo-induced antigen technology (IVIAT) has also been performed to screen a library of Salmonella proteins to identify bacterial antigens expressed during human infection [139]. Improving the limit of detection remains to be resolved for obtaining a more comprehensive dataset.

Immunoglobulin isotypes against bacterial antigens found in infected people can be used as an indicator to reflect various infection stages. For example, the presence of $\operatorname{IgM}$ and IgA against $S$. Typhi antigens without high levels of IgG suggests acute infection [135]. In contrast, higher levels of IgG against bacterial antigens can indicate acute and chronic infection stages, depending on the vaccination and preinfection history of suspected patients. Salmonella-activated lymphocytes secreting mucosa-derived IgA were detected in peripheral blood as early as 3 days after infection, reaching peak level by Day $7[140,141]$. In some cases, modifications in procedures, such as the isolation and transient in vitro culture of activated lymphocytes, have been implemented to maximize IgA detection. Similarly, antibodies were detected from lymphocyte supernatant (antibodies in lymphocyte supernatant or ALS) [142]. Such methods improved the limit of antibody detection compared to the procedures using patient plasma samples, indicating a promise of early disease diagnosis.

Antigens such as HlyE and LPS exhibit high diagnostic potential [143]. HlyE is relatively unique to $S$. Typhi and $S$. Paratyphi since this gene product is absent from most 
NTS, including S. Typhimurium and S. Enteritidis [106]. Although HlyE homologs are present in E. coli, IgA-HlyE could discriminate enteric fever from other febrile infections, including NTS [144]. Various studies have demonstrated that elevated levels of both IgA and IgG in the tested patient samples, which show a promise in differentiating acute enteric fever patients who may be reinfected or vaccinated [144-148]. Furthermore, a noninvasive method using saliva samples, measuring IgA-HlyE antibodies via an ELISAbased method [149], was also tested.

Additionally, multiple antigens have been investigated simultaneously to achieve the highest accuracy in bacterial detection. One such assay format included a multiplex immunochromatographic strip detecting both IgA-HlyE and IgA-LPS, which exhibited a high diagnostic accuracy $[145,150]$. Here, HlyE can discriminate enteric fever from other febrile infections, while LPS distinguishes enteric fever from healthy groups. Similarly, several studies have demonstrated the promise of $\mathrm{CdtB}$, an enzymatic subunit of typhoid toxin that is produced only during infection, as a biomarker for acute enteric fever diagnosis. Significantly increased levels of IgG-CdtB in enteric fever patient plasma and ALS samples were detected, indicating its serodiagnostic potential [132,133,135]. IgM-CdtB has also been detected but at a lower level using standard ELISA methods [151]. While typhoid toxin orthologs are encoded in the genomes of some NTS serovars, their target host cells are intestinal epithelial cells that produce different clinical presentations [123]. Amino acid sequence variations on glycan receptor binding pockets of typhoid toxin orthologs are responsible for a narrow host cell tropism [123]. To make this biomarker a more reliable diagnostic method, some changes should be made to improve the detection limit and/or use it as part of signatures that can be combined with other biomarkers, such as Vi polysaccharides [152], LPS, and other membrane components [142].

ELISA and an immunodot blot method called TPTest, evaluating IgA titers against membrane components of $S$. Typhi and S. Paratyphi using ALS samples, exhibited 78-97\% specificity and $100 \%$ sensitivity in detecting the bacteria $[129,142,153]$. TPTest is advantageous in differentiating acute infection from convalescence, which would make this test a valuable tool for disease diagnosis in endemic areas [153]. With additional improvements, these biomarkers could be developed as POC-compatible rapid diagnostic methods.

\subsubsection{Nucleic Acid Biomarkers}

Using transcriptional profiling approaches such as microarray hybridization and RNA-Seq, gene expression profiles of bacterial and host cells that occurred during various infection stages have been analyzed, resulting in the discovery of new biomarkers. For instance, microarray analysis detected 2026 S. Typhi genes ( $44 \%$ of the genome) from infected blood cells, with 141 transcripts upregulated, including PhoPQ regulatory genes, the typhoid toxin, and HlyE [154]. Microarray analysis has also been exploited to identify host genes. Relative gene expression pattern analysis of peripheral blood samples reflecting acute, recovery, convalescent, and uninfected groups for enteric fever produced reproducible blood signatures specific to the disease [155]. The transcripts identified in this study were correlated to clinical parameters [155]. Investigators of this study noted the need for careful data interpretation to avoid a possible cumulative effect of responses as blood represents both a pool and a migration compartment for various immune cell types.

A more recent study investigated five host genes as a signature (STAT1, SLAMF8, PSME2, WARS, and ALDH1A1) that was able to identify enteric fever with $88 \%$ specificity and $97 \%$ sensitivity [156]. If these signatures are also observed in different endemic areas, amplification of such genes by qPCR-based diagnostic assay can be developed as a promising diagnostic method. A novel method named miniature NMR ( $\mu$ NMR), detecting bacterial mRNA using magneto-DNA probes, has been proposed; it is capable of detecting up to $1 \mathrm{CFU} / \mathrm{mL} S$. Typhi and S. Paratyphi [140], indicating the promise of developing an ultrasensitive detection method. Some tweaks may be required as detecting mRNA may be more challenging than detecting DNA due to the relatively unstable nature of bacterial mRNA. 


\subsubsection{Metabolite Biomarkers}

To understand specific metabolic changes occurring in enteric fever patients, metabolo mics has been conducted. For instance, comparative analysis of metabolites between patient plasma samples infected with $S$. Typhi or $S$. Paratyphi and control samples via gas chromatography-mass spectrometry approaches identified 695 distinct metabolite peaks [157]. A combined analysis of highly reproducible top 6 peaks, reflecting ethanolamine, gluconic acid, monosaccharide, phenylalanine, pipecolic acid, and saccharide, was able to distinguish typhoid fever patients from paratyphoid fever patients and healthy individuals. A tight correlation of other metabolites, such as iron and tryptophan, to typhoid fever has also been demonstrated. S. Typhi induced a rapid decline of plasma iron levels and the retention of iron inside tissue macrophages through the upregulation of hepcidin [158]. Acute infection with $S$. Typhi generates a specific interferon signature that alters tryptophan catabolic pathways, leading to the pathogenesis of typhoid fever [159]. Identifying any single or combined differentially induced metabolites during the different infection stages could discover promising novel biomarkers. Further studies covering sufficient sample size and other febrile disease samples also prevalent in endemic areas are anticipated to result in a much-improved enteric fever diagnostic method.

\section{Concluding Remarks}

Current enteric fever diagnostics such as culture-based methods exhibit superior specificity but suffer from low sensitivity and relatively slow turnaround time. PCR-based nucleic acid detection methods are reasonably rapid but require trained personnel and special equipment to conduct. Serological methods exemplified by the Widal test are quick and, therefore, highly POC-compatible in endemic areas but exhibit modest specificity and sensitivity. Toward the establishment of optimal diagnostic methods, several highthroughput approaches have been carried out to search for bacterial and host biomarkers that are relatively unique for enteric fever and differentiating acute, recovery, and convalescent infection stages. The currently available data are not sufficient to point out a single ideal biomarker. However, these results will serve as the groundwork for future efforts. For instance, if we decide to go with a single or few biomarkers available from the completed approaches, a breakthrough from standard detection methods leading to ultrasensitive detections of such biomarkers should be made. If we decide to use traditional detection methods, a cost-effective signature biomarker panel that differentiates enteric fever from other febrile diseases and healthy/healthy-recovered individuals who have been previously exposed to pathogens should be established. Moreover, the discussed high-end technologies (e.g., proteomics, transcriptomics, and metabolomics) are not compatible with the lack of infrastructure in endemic areas. Therefore, there is a need to identify cheaper and simpler methods or convert these technologies into something more accessible. The reality is that the most important factor in diagnosing $S$. Typhi and S. Paratyphi infections in endemic regions is finding something that is inexpensive and easy to use. Lastly, although it is less straightforward, future efforts should include developing diagnostic methods detecting healthy/asymptomatic chronic carriers of these human-specific pathogens.

Author Contributions: D.P.N. designed the article, interpreted the relevant literature, and wrote the draft. H.P.D. contributed to the design of the article. J.S. designed the article, interpreted the relevant literature, and revised the manuscript. All authors have read and agreed to the published version of the manuscript.

Funding: This work was supported in part by NIH R01 AI137345, AI139625, and AI141514 and the USDA/NIFA Hatch project 1017170 grant to J.S.

Institutional Review Board Statement: Not applicable.

Informed Consent Statement: Not applicable.

Data Availability Statement: This paper contains all data.

Conflicts of Interest: The authors declare no conflict of interest. 


\section{References}

1. Ochiai, R.L.; Acosta, C.J.; Danovaro-Holliday, M.C.; Baiqing, D.; Bhattacharya, S.K.; Agtini, M.D.; Bhutta, Z.A.; Canh, D.G.; Ali, M.; Shin, S.; et al. A study of typhoid fever in five Asian countries: Disease burden and implications for controls. Bull. World Health Organ. 2008, 86, 260-268. [CrossRef] [PubMed]

2. MacFadden, D.R.; Bogoch, I.I.; Andrews, J.R. Advances in diagnosis, treatment, and prevention of invasive Salmonella infections. Curr. Opin. Infect. Dis. 2016, 29, 453-458. [CrossRef] [PubMed]

3. Baker, S.; Favorov, M.; Dougan, G. Searching for the elusive typhoid diagnostic. BMC Infect. Dis. 2010, 10, 45. [CrossRef] [PubMed]

4. $\quad$ Brenner, F.W.; Villar, R.G.; Angulo, F.J.; Tauxe, R.; Swaminathan, B. Salmonella nomenclature. J. Clin. Microbiol. 2000, 38 , $2465-2467$. [CrossRef]

5. Uzzau, S.; Brown, D.J.; Wallis, T.; Rubino, S.; Leori, G.; Bernard, S.; Casadesús, J.; Platt, D.J.; Olsen, J.E. Host adapted serotypes of Salmonella enterica. Epidemiol. Infect. 2000, 125, 229-255. [CrossRef]

6. Velge, P.; Cloeckaert, A.; Barrow, P. Emergence of Salmonella epidemics: The problems related to Salmonella enterica serotype Enteritidis and multiple antibiotic resistance in other major serotypes. Vet. Res. 2005, 36, 267-288. [CrossRef]

7. Feasey, N.A.; Dougan, G.; Kingsley, R.A.; Heyderman, R.S.; Gordon, M.A. Invasive non-typhoidal salmonella disease: An emerging and neglected tropical disease in Africa. Lancet 2012, 379, 2489-2499. [CrossRef]

8. Khan, M.I.; Soofi, S.B.; Ochiai, R.L.; Khan, M.J.; Sahito, S.M.; Habib, M.A.; Puri, M.K.; von Seidlein, L.; Park, J.K.; You, Y.A.; et al. Epidemiology, clinical presentation, and patterns of drug resistance of Salmonella Typhi in Karachi, Pakistan. J. Infect. Dev. Ctries. 2012, 6, 704-714. [CrossRef]

9. Waddington, C.S.; Darton, T.C.; Jones, C.; Haworth, K.; Peters, A.; John, T.; Thompson, B.A.; Kerridge, S.A.; Kingsley, R.A.; Zhou, L.; et al. An outpatient, ambulant-design, controlled human infection model using escalating doses of Salmonella Typhi challenge delivered in sodium bicarbonate solution. Clin. Infect. Dis. 2014, 58, 1230-1240. [CrossRef]

10. Dunstan, S.J.; Stephens, H.A.; Blackwell, J.M.; Duc, C.M.; Lanh, M.N.; Dudbridge, F.; Phuong, C.X.; Luxemburger, C.; Wain, J.; Ho, V.A.; et al. Genes of the class II and class III major histocompatibility complex are associated with typhoid fever in Vietnam. J. Infect. Dis. 2001, 183, 261-268. [CrossRef]

11. van de Vosse, E.; Ali, S.; de Visser, A.W.; Surjadi, C.; Widjaja, S.; Vollaard, A.M.; van Dissel, J.T. Susceptibility to typhoid fever is associated with a polymorphism in the cystic fibrosis transmembrane conductance regulator (CFTR). Hum. Genet. 2005, 118, 138-140. [CrossRef]

12. Maskey, A.P.; Day, J.N.; Phung, Q.T.; Thwaites, G.E.; Campbell, J.I.; Zimmerman, M.; Farrar, J.J.; Basnyat, B. Salmonella enterica serovar Paratyphi A and S. enterica serovar Typhi cause indistinguishable clinical syndromes in Kathmandu, Nepal. Clin. Infect. Dis. 2006, 42, 1247-1253. [CrossRef]

13. Stanaway, J.D.; Reiner, R.C.; Blacker, B.F.; Goldberg, E.M.; Khalil, I.A.; Troeger, C.E.; Andrews, J.R.; Bhutta, Z.A.; Crump, J.A.; Im, J.; et al. The global burden of typhoid and paratyphoid fevers: A systematic analysis for the Global Burden of Disease Study 2017. Lancet Infect. Dis. 2019, 19, 369-381. [CrossRef]

14. Sejvar, J.; Lutterloh, E.; Naiene, J.; Likaka, A.; Manda, R.; Nygren, B.; Monroe, S.; Khaila, T.; Lowther, S.A.; Capewell, L.; et al. Neurologic manifestations associated with an outbreak of typhoid fever, Malawi-Mozambique, 2009: An epidemiologic investigation. PLoS ONE 2012, 7, e46099. [CrossRef]

15. Crump, J.A.; Sjölund-Karlsson, M.; Gordon, M.A.; Parry, C.M. Epidemiology, Clinical Presentation, Laboratory Diagnosis, Antimicrobial Resistance, and Antimicrobial Management of Invasive Salmonella Infections. Clin. Microbiol. Rev. 2015, $28,901-937$. [CrossRef] [PubMed]

16. Crump, J.A. Typhoid Fever and the challenge of nonmalaria febrile illness in sub-saharan Africa. Clin. Infect. Dis. 2012, 54, 1107-1109. [CrossRef] [PubMed]

17. Olarte, J.; Galindo, E. Salmonella typhi resistant to chloramphenicol, ampicillin, and other antimicrobial agents: Strains isolated during an extensive typhoid fever epidemic in Mexico. Antimicrob. Agents Chemother. 1973, 4, 597-601. [CrossRef] [PubMed]

18. Roumagnac, P.; Weill, F.X.; Dolecek, C.; Baker, S.; Brisse, S.; Chinh, N.T.; Le, T.A.; Acosta, C.J.; Farrar, J.; Dougan, G.; et al. Evolutionary history of Salmonella typhi. Science 2006, 314, 1301-1304. [CrossRef]

19. Akhtar, S.; Sarker, M.R.; Jabeen, K.; Sattar, A.; Qamar, A.; Fasih, N. Antimicrobial resistance in Salmonella enterica serovar typhi and paratyphi in South Asia-current status, issues and prospects. Crit. Rev. Microbiol. 2015, 41, 536-545. [CrossRef] [PubMed]

20. Holt, K.E.; Phan, M.D.; Baker, S.; Duy, P.T.; Nga, T.V.; Nair, S.; Turner, A.K.; Walsh, C.; Fanning, S.; Farrell-Ward, S.; et al. Emergence of a globally dominant IncHI1 plasmid type associated with multiple drug resistant typhoid. PLoS Negl. Trop. Dis. 2011, 5, e1245. [CrossRef]

21. Wong, V.K.; Baker, S.; Pickard, D.J.; Parkhill, J.; Page, A.J.; Feasey, N.A.; Kingsley, R.A.; Thomson, N.R.; Keane, J.A.; Weill, F.X.; et al. Phylogeographical analysis of the dominant multidrug-resistant H58 clade of Salmonella Typhi identifies inter- and intracontinental transmission events. Nat. Genet. 2015, 47, 632-639. [CrossRef] [PubMed]

22. Baker, S.; Holt, K.E.; Clements, A.C.; Karkey, A.; Arjyal, A.; Boni, M.F.; Dongol, S.; Hammond, N.; Koirala, S.; Duy, P.T.; et al. Combined high-resolution genotyping and geospatial analysis reveals modes of endemic urban typhoid fever transmission. Open Biol. 2011, 1, 110008. [CrossRef] 
23. Holt, K.E.; Dolecek, C.; Chau, T.T.; Duy, P.T.; La, T.T.; Hoang, N.V.; Nga, T.V.; Campbell, J.I.; Manh, B.H.; Chau, N.V.V.; et al. Temporal fluctuation of multidrug resistant salmonella typhi haplotypes in the mekong river delta region of Vietnam. PLoS Negl. Trop. Dis. 2011, 5, e929. [CrossRef]

24. Yan, M.; Li, X.; Liao, Q.; Li, F.; Zhang, J.; Kan, B. The emergence and outbreak of multidrug-resistant typhoid fever in China. Emerg. Microbes Infect. 2016, 5, e62. [CrossRef]

25. Ingle, D.J.; Nair, S.; Hartman, H.; Ashton, P.M.; Dyson, Z.A.; Day, M.; Freedman, J.; Chattaway, M.A.; Holt, K.E.; Dallman, T.J. Informal genomic surveillance of regional distribution of Salmonella Typhi genotypes and antimicrobial resistance via returning travellers. PLoS Negl. Trop. Dis. 2019, 13, e0007620. [CrossRef]

26. Chiou, C.S.; Lauderdale, T.L.; Phung, D.C.; Watanabe, H.; Kuo, J.C.; Wang, P.J.; Liu, Y.Y.; Liang, S.Y.; Chen, P.C. Antimicrobial resistance in Salmonella enterica Serovar Typhi isolates from Bangladesh, Indonesia, Taiwan, and Vietnam. Antimicrob. Agents Chemother. 2014, 58, 6501-6507. [CrossRef]

27. Klemm, E.J.; Shakoor, S.; Page, A.J.; Qamar, F.N.; Judge, K.; Saeed, D.K.; Wong, V.K.; Dallman, T.J.; Nair, S.; Baker, S.; et al. Emergence of an Extensively Drug-Resistant Salmonella enterica Serovar Typhi Clone Harboring a Promiscuous Plasmid Encoding Resistance to Fluoroquinolones and Third-Generation Cephalosporins. mBio 2018, 9, e00105-18. [CrossRef] [PubMed]

28. Chatham-Stephens, K.; Medalla, F.; Hughes, M.; Appiah, G.D.; Aubert, R.D.; Caidi, H.; Angelo, K.M.; Walker, A.T.; Hatley, N.; Masani, S.; et al. Emergence of Extensively Drug-Resistant Salmonella Typhi Infections Among Travelers to or from PakistanUnited States, 2016-2018. MMWR Morb. Mortal. Wkly. Rep. 2019, 68, 11-13. [CrossRef]

29. Wong, W.; Rawahi, H.A.; Patel, S.; Yau, Y.; Eshaghi, A.; Zittermann, S.; Tattum, L.; Morris, S.K. The first Canadian pediatric case of extensively drug-resistant Salmonella Typhi originating from an outbreak in Pakistan and its implication for empiric antimicrobial choices. IDCases 2019, 15, e00492. [CrossRef]

30. López-Segura, N.; Corberó-Rivali, C.; Maldonado-Fernández, M.C.; Calpe-Fraile, S.; Peyra-Ros, J.; Martínez-Roig, A. Imported extensively drug resistant typhoid fever in a child travelling to Spain from Pakistan. J. Travel Med. 2019, 26, taz066. [CrossRef] [PubMed]

31. Holubar, M. Antimicrobial resistance: A global public health emergency further exacerbated by international travel. J. Travel Med. 2020, 27, taz095. [CrossRef] [PubMed]

32. Parry, C.M.; Thieu, N.T.; Dolecek, C.; Karkey, A.; Gupta, R.; Turner, P.; Dance, D.; Maude, R.R.; Ha, V.; Tran, C.N.; et al. Clinically and microbiologically derived azithromycin susceptibility breakpoints for Salmonella enterica serovars Typhi and Paratyphi, A. Antimicrob. Agents Chemother. 2015, 59, 2756-2764. [CrossRef]

33. Patel, S.R.; Bharti, S.; Pratap, C.B.; Nath, G. Drug Resistance Pattern in the Recent Isolates of Salmonella Typhi with Special Reference to Cephalosporins and Azithromycin in the Gangetic Plain. J. Clin. Diagn. Res. 2017, 11, Dm01-Dm03. [CrossRef]

34. Hooda, Y.; Sajib, M.S.I.; Rahman, H.; Luby, S.P.; Bondy-Denomy, J.; Santosham, M.; Andrews, J.R.; Saha, S.K.; Saha, S. Molecular mechanism of azithromycin resistance among typhoidal Salmonella strains in Bangladesh identified through passive pediatric surveillance. PLoS Negl. Trop. Dis. 2019, 13, e0007868. [CrossRef]

35. Fernández, J.; Guerra, B.; Rodicio, M.R. Resistance to Carbapenems in Non-Typhoidal Salmonella enterica Serovars from Humans, Animals and Food. Vet. Sci. 2018, 5, 40. [CrossRef]

36. Levine, M.M.; Black, R.E.; Lanata, C. Precise estimation of the numbers of chronic carriers of Salmonella typhi in Santiago, Chile, an endemic area. J. Infect. Dis. 1982, 146, 724-726. [CrossRef] [PubMed]

37. Caygill, C.P.; Braddick, M.; Hill, M.J.; Knowles, R.L.; Sharp, J.C. The association between typhoid carriage, typhoid infection and subsequent cancer at a number of sites. Eur. J. Cancer Prev. 1995, 4, 187-193. [CrossRef] [PubMed]

38. Cvjetanović, B.; Grab, B.; Uemura, K. Epidemiological model of typhoid fever and its use in the planning and evaluation of antityphoid immunization and sanitation programmes. Bull. World Health Organ. 1971, 45, 53-75.

39. Gunn, J.S.; Marshall, J.M.; Baker, S.; Dongol, S.; Charles, R.C.; Ryan, E.T. Salmonella chronic carriage: Epidemiology, diagnosis, and gallbladder persistence. Trends Microbiol. 2014, 22, 648-655. [CrossRef] [PubMed]

40. WHO. World Health Organization Background Document: The Diagnosis, Treatment, and Prevention of Typhoid Fever; World Health Organization Department of Vaccines and Biologicals: Geneva, Switzerland, 2003.

41. Wain, J.; Pham, V.B.; Ha, V.; Nguyen, N.M.; To, S.D.; Walsh, A.L.; Parry, C.M.; Hasserjian, R.P.; HoHo, V.A.; Tran, T.H.; et al. Quantitation of bacteria in bone marrow from patients with typhoid fever: Relationship between counts and clinical features. J. Clin. Microbiol. 2001, 39, 1571-1576. [CrossRef]

42. Gilman, R.H.; Terminel, M.; Levine, M.M.; Hernandez-Mendoza, P.; Hornick, R.B. Relative efficacy of blood, urine, rectal swab, bone-marrow, and rose-spot cultures for recovery of Salmonella typhi in typhoid fever. Lancet 1975, 1, 1211-1213. [CrossRef]

43. Kaye, D.; Palmieri, M.; Rocha, H. Effect of bile on the action of blood against Salmonella. J. Bacteriol. 1966, 91, 945-952. [CrossRef]

44. Haebler, T.; Miles, A. The action of sodium polyanethol sulfonate ("Liquoid") on blood cultures. J. Pathol. Bacteriol. 1938, 46, 245-252. [CrossRef]

45. Escamilla, J.; Santiago, L.T.; Uylangco, C.V.; Cross, J.H. Evaluation of sodium polyanethanol sulfonate as a blood culture additive for recovery of Salmonella typhi and Salmonella paratyphi A. J. Clin. Microbiol. 1983, 18, 380-383. [CrossRef] [PubMed]

46. Mantur, B.G.; Bidari, L.H.; Akki, A.S.; Mulimani, M.S.; Tikare, N.V. Diagnostic yield of blood clot culture in the accurate diagnosis of enteric fever and human brucellosis. Clin. Lab. 2007, 53, 57-61. [PubMed]

47. Watson, K.C. Clot culture in typhoid fever. J. Clin. Pathol. 1954, 7, 305-307. [CrossRef] 
48. Saha, S.K.; Darmstadt, G.L.; Baqui, A.H.; Hanif, M.; Ruhulamin, M.; Santosham, M.; Nagatake, T.; Black, R.E. Rapid identification and antibiotic susceptibility testing of Salmonella enterica serovar Typhi isolated from blood: Implications for therapy. J. Clin. Microbiol. 2001, 39, 3583-3585. [CrossRef] [PubMed]

49. Watson, K.C. Isolation of Salmonella typhi from the blood stream. J. Lab. Clin. Med. 1955, 46, 128-134.

50. Cockerill, F.R., III; Wilson, J.W.; Vetter, E.A.; Goodman, K.M.; Torgerson, C.A.; Harmsen, W.S.; Schleck, C.D.; Ilstrup, D.M.; Washington, J.A., 2nd; Wilson, W.R. Optimal testing parameters for blood cultures. Clin. Infect. Dis. 2004, 38, 1724-1730. [CrossRef]

51. Edelman, R.; Levine, M.M. Summary of an international workshop on typhoid fever. Rev. Infect. Dis. 1986, 8, 329-349. [CrossRef]

52. Farooqui, B.J.; Khurshid, M.; Ashfaq, M.K.; Khan, M.A. Comparative yield of Salmonella typhi from blood and bone marrow cultures in patients with fever of unknown origin. J. Clin. Pathol. 1991, 44, 258-259. [CrossRef] [PubMed]

53. Sinha, A.; Sazawal, S.; Kumar, R.; Sood, S.; Reddaiah, V.P.; Singh, B.; Rao, M.; Naficy, A.; Clemens, J.D.; Bhan, M.K. Typhoid fever in children aged less than 5 years. Lancet 1999, 354, 734-737. [CrossRef]

54. Gasem, M.H.; Dolmans, W.M.; Isbandrio, B.B.; Wahyono, H.; Keuter, M.; Djokomoeljanto, R. Culture of Salmonella typhi and Salmonella paratyphi from blood and bone marrow in suspected typhoid fever. Trop. Geogr. Med. 1995, 47, 164-167. [PubMed]

55. Vallenas, C.; Hernandez, H.; Kay, B.; Black, R.; Gotuzzo, E. Efficacy of bone marrow, blood, stool and duodenal contents cultures for bacteriologic confirmation of typhoid fever in children. Pediatr. Infect. Dis. 1985, 4, 496-498. [CrossRef]

56. Nizami, S.Q.; Bhutta, Z.A.; Siddiqui, A.A.; Lubbad, L. Enhanced detection rate of typhoid fever in children in a periurban slum in Karachi, Pakistan using polymerase chain reaction technology. Scand. J. Clin. Lab. Invest. 2006, 66, 429-436. [CrossRef]

57. Song, J.H.; Cho, H.; Park, M.Y.; Na, D.S.; Moon, H.B.; Pai, C.H. Detection of Salmonella typhi in the blood of patients with typhoid fever by polymerase chain reaction. J. Clin. Microbiol. 1993, 31, 1439-1443. [CrossRef]

58. Ali, A.; Haque, A.; Haque, A.; Sarwar, Y.; Mohsin, M.; Bashir, S.; Tariq, A. Multiplex PCR for differential diagnosis of emerging typhoidal pathogens directly from blood samples. Epidemiol. Infect. 2009, 137, 102-107. [CrossRef]

59. Zhu, Q.; Lim, C.K.; Chan, Y.N. Detection of Salmonella typhi by polymerase chain reaction. J. Appl. Bacteriol. 1996, 80, $244-251$. [CrossRef]

60. Ambati, S.R.; Nath, G.; Das, B.K. Diagnosis of typhoid fever by polymerase chain reaction. Indian, J. Pediatr. 2007, 74, 909-913. [CrossRef]

61. Kumar, A.; Arora, V.; Bashamboo, A.; Ali, S. Detection of Salmonella typhi by polymerase chain reaction: Implications in diagnosis of typhoid fever. Infect. Genet. Evol. 2002, 2, 107-110. [CrossRef]

62. Massi, M.N.; Shirakawa, T.; Gotoh, A.; Bishnu, A.; Hatta, M.; Kawabata, M. Quantitative detection of Salmonella enterica serovar Typhi from blood of suspected typhoid fever patients by real-time PCR. Int. J. Med. Microbiol. 2005, 295, 117-120.

63. Nga, T.V.; Karkey, A.; Dongol, S.; Thuy, H.N.; Dunstan, S.; Holt, K.; Le, T.P.T.; Campbell, J.I.; Chau, T.T.; Chau, N.V.; et al. The sensitivity of real-time PCR amplification targeting invasive Salmonella serovars in biological specimens. BMC Infect. Dis. 2010, 10, 125. [CrossRef]

64. Tennant, S.M.; Toema, D.; Qamar, F.; Iqbal, N.; Boyd, M.A.; Marshall, J.M.; Blackwelder, W.C.; Wu, Y.; Quadri, F.; Khan, A.; et al. Detection of Typhoidal and Paratyphoidal Salmonella in Blood by Real-time Polymerase Chain Reaction. Clin. Infect. Dis. 2015, 61 (Suppl. S4), S241-S250. [CrossRef]

65. Zhou, L.; Pollard, A.J. A novel method of selective removal of human DNA improves PCR sensitivity for detection of Salmonella Typhi in blood samples. BMC Infect. Dis. 2012, 12, 164. [CrossRef] [PubMed]

66. Darton, T.C.; Zhou, L.; Blohmke, C.J.; Jones, C.; Waddington, C.S.; Baker, S.; Pollard, A.J. Blood culture-PCR to optimise typhoid fever diagnosis after controlled human infection identifies frequent asymptomatic cases and evidence of primary bacteraemia. $J$. Infect. 2017, 74, 358-366. [CrossRef] [PubMed]

67. Lanata, C.F.; Levine, M.M.; Ristori, C.; Black, R.E.; Jimenez, L.; Salcedo, M.; Garcia, J.; Sotomayor, V. Vi serology in detection of chronic Salmonella typhi carriers in an endemic area. Lancet 1983, 2, 441-443. [CrossRef]

68. Zhang, H.; Zhou, Y.; Bao, H.; Liu, H.W. Vi antigen biosynthesis in Salmonella typhi: Characterization of UDP-N-acetylglucosamine C-6 dehydrogenase (TviB) and UDP-N-acetylglucosaminuronic acid C-4 epimerase (TviC). Biochemistry 2006, 45, 8163-8173. [CrossRef] [PubMed]

69. Virlogeux, I.; Waxin, H.; Ecobichon, C.; Popoff, M.Y. Role of the viaB locus in synthesis, transport and expression of Salmonella typhi Vi antigen. Microbiology 1995, 141 Pt 12, 3039-3047. [CrossRef]

70. Virlogeux, I.; Waxin, H.; Ecobichon, C.; Lee, J.O.; Popoff, M.Y. Characterization of the rcsA and rcsB genes from Salmonella typhi: rcsB through tviA is involved in regulation of Vi antigen synthesis. J. Bacteriol. 1996, 178, 1691-1698. [CrossRef]

71. Pickard, D.; Wain, J.; Baker, S.; Line, A.; Chohan, S.; Fookes, M.; Barron, A.; Gaora, P.O.; Chabalgoity, J.A.; Thanky, N.; et al. Composition, acquisition, and distribution of the Vi exopolysaccharide-encoding Salmonella enterica pathogenicity island SPI-7. J. Bacteriol. 2003, 185, 5055-5065. [CrossRef]

72. Baker, S.; Sarwar, Y.; Aziz, H.; Haque, A.; Ali, A.; Dougan, G.; Wain, J.; Haque, A. Detection of Vi-negative Salmonella enterica serovar typhi in the peripheral blood of patients with typhoid fever in the Faisalabad region of Pakistan. J. Clin. Microbiol. 2005, 43, 4418-4425. [CrossRef]

73. Pickard, D.; Li, J.; Roberts, M.; Maskell, D.; Hone, D.; Levine, M.; Dougan, G.; Chatfield, S. Characterization of defined ompR mutants of Salmonella typhi: ompR is involved in the regulation of Vi polysaccharide expression. Infect. Immun. 1994, 62, 3984-3993. [CrossRef] [PubMed] 
74. Brewer, S.M.; Twittenhoff, C.; Kortmann, J.; Brubaker, S.W.; Honeycutt, J.; Massis, L.M.; Pham, T.H.M.; Narberhau, F.; Monack, D.M. A salmonella typhi rna thermosensor regulates virulence factors and innate immune evasion in response to host temperature. PLoS Pathog. 2021, 17, e1009345. [CrossRef]

75. Luk, J.M.; Kongmuang, U.; Reeves, P.R.; Lindberg, A.A. Selective amplification of abequose and paratose synthase genes (rfb) by polymerase chain reaction for identification of Salmonella major serogroups (A, B, C2, and D). J. Clin. Microbiol. 1993, 31, $2118-2123$. [CrossRef]

76. Popoff, M.Y.; Bockemühl, J.; Gheesling, L.L. Supplement 2001 (no. 45) to the Kauffmann-White scheme. Res. Microbiol. 2003, 154, 173-174. [CrossRef]

77. Wang, L.; Wang, Q.; Reeves, P.R. The variation of O antigens in gram-negative bacteria. Subcell. Biochem. 2010, 53, 123-152.

78. Wain, J.D.; House, A.; Zafar, S.; Baker, S.; Nair, C.; Kidgell, Z.; Bhutta, G. Dougan and R. Hasan. Vi antigen expression in Salmonella enterica serovar Typhi clinical isolates from Pakistan. J. Clin. Microbiol. 2005, 43, 1158-1165. [CrossRef]

79. Silverman, M.; Simon, M. Phase variation: Genetic analysis of switching mutants. Cell 1980, 19, 845-854. [CrossRef]

80. Frankel, G.; Newton, S.M.; Schoolnik, G.K.; Stocker, B.A. Intragenic recombination in a flagellin gene: Characterization of the H1-j gene of Salmonella typhi. EMBO J. 1989, 8, 3149-3152. [CrossRef]

81. Baker, S.; Hardy, J.; Sanderson, K.E.; Quail, M.; Goodhead, I.; Kingsley, R.A.; Parkhill, J.; Stocker, B.; Dougan, G. A novel linear plasmid mediates flagellar variation in Salmonella Typhi. PLoS Pathog. 2007, 3, e59. [CrossRef]

82. Levine, M.M.; Grados, O.; Gilman, R.H.; Woodward, W.E.; Solis-Plaza, R.; Waldman, W. Diagnostic value of the Widal test in areas endemic for typhoid fever. Am. J. Trop. Med. Hyg. 1978, 27, 795-800. [CrossRef]

83. Rodrigues, C. The Widal test-More than 100 years old: Abused but still used. J. Assoc. Physicians India 2003, 51, 7-8.

84. House, D.; Chinh, N.T.; Diep, T.S.; Parry, C.M.; Wain, J.; Dougan, G.; White, N.J.; Hien, T.T.; Farrar, J.J. Use of paired serum samples for serodiagnosis of typhoid fever. J. Clin. Microbiol. 2005, 43, 4889-4890. [CrossRef] [PubMed]

85. Parry, C.M.; Hoa, N.T.; Diep, T.S.; Wain, J.; Chinh, N.T.; Vinh, H.; Hien, T.T.; White, N.J.; Farrar, J.J. Value of a single-tube widal test in diagnosis of typhoid fever in Vietnam. J. Clin. Microbiol. 1999, 37, 2882-2886. [CrossRef] [PubMed]

86. Kulkarni, M.L.; Rego, S.J. Value of single Widal test in the diagnosis of typhoid fever. Indian Pediatr. 1994, 31, $1373-1377$.

87. Clegg, A.; Passey, M.; Omena, M.; Karigifa, K.; Suve, N. Re-evaluation of the Widal agglutination test in response to the changing pattern of typhoid fever in the highlands of Papua New Guinea. Acta Trop. 1994, 57, 255-263. [CrossRef]

88. Dutta, S.; Sur, D.; Manna, B.; Sen, B.; Deb, A.K.; Deen, J.L.; Wain, J.; von Seidlein, L.; Ochiai, L.; Clemens, J.D.; et al. Evaluation of new-generation serologic tests for the diagnosis of typhoid fever: Data from a community-based surveillance in Calcutta, India. Diagn. Microbiol. Infect. Dis. 2006, 56, 359-365. [CrossRef] [PubMed]

89. Espersen, F.; Høiby, N.; Hertz, J.B. Cross-reactions between Salmonella typhi and 24 other bacterial species. Acta Pathol. Microbiol. Scand. B 1980, 88, 243-248. [CrossRef]

90. Wijedoru, L.; Mallett, S.; Parry, C.M. Rapid diagnostic tests for typhoid and paratyphoid (enteric) fever. Cochrane Database Syst. Rev. 2017, 5, Cd008892. [CrossRef]

91. Lim, P.L.; Tam, F.C.; Cheong, Y.M.; Jegathesan, M. One-step 2-minute test to detect typhoid-specific antibodies based on particle separation in tubes. J. Clin. Microbiol. 1998, 36, 2271-2278. [CrossRef] [PubMed]

92. Tam, F.C.; Wang, M.; Dong, B.; Leung, D.T.; Ma, C.H.; Lim, P.L. New rapid test for paratyphoid a fever: Usefulness, cross-detection, and solution. Diagn. Microbiol. Infect. Dis. 2008, 62, 142-150. [CrossRef]

93. Choo, K.E.; Davis, T.M.; Ismail, A.; Ibrahim, T.A.T.; Ghazali, W.N. Rapid and reliable serological diagnosis of enteric fever: Comparative sensitivity and specificity of Typhidot and Typhidot-M tests in febrile Malaysian children. Acta Trop. 1999, 72, 175-183. [CrossRef]

94. Bhutta, Z.A.; Mansurali, N. Rapid serologic diagnosis of pediatric typhoid fever in an endemic area: A prospective comparative evaluation of two dot-enzyme immunoassays and the Widal test. Am. J. Trop. Med. Hyg. 1999, 61, 654-657. [CrossRef] [PubMed]

95. Baker, S.; Dougan, G. The genome of Salmonella enterica serovar Typhi. Clin. Infect. Dis. 2007, 45 (Suppl. S1), S29-S33. [CrossRef]

96. Parkhill, J.; Dougan, G.; James, K.D.; Thomson, N.R.; Pickard, D.; Wain, J.; Churcher, C.; Mungall, K.L.; Bentley, S.D.; Holden, M.T.; et al. Complete genome sequence of a multiple drug resistant Salmonella enterica serovar Typhi CT18. Nature 2001, 413, 848-852. [CrossRef]

97. McClelland, M.; Sanderson, K.E.; Spieth, J.; Clifton, S.W.; Latreille, P.; Courtney, L.; Porwollik, S.; Ali, J.; Dante, M.; Du, F.; et al. Complete genome sequence of Salmonella enterica serovar Typhimurium LT2. Nature 2001, 413, 852-856. [CrossRef] [PubMed]

98. Crosa, J.H.; Brenner, D.J.; Ewing, W.H.; Falkow, S. Molecular relationships among the Salmonelleae. J. Bacteriol. 1973, 115, 307-315. [CrossRef]

99. McClelland, M.; Sanderson, K.E.; Clifton, S.W.; Latreille, P.; Porwollik, S.; Sabo, A.; Meyer, R.; Bieri, T.; Ozersky, P.; McLellan, M.; et al. Comparison of genome degradation in Paratyphi A and Typhi, human-restricted serovars of Salmonella enterica that cause typhoid. Nat. Genet. 2004, 36, 1268-1274. [CrossRef] [PubMed]

100. Holt, K.E.; Thomson, N.R.; Wain, J.; Langridge, G.C.; Hasan, R.; Bhutta, Z.A.; Quail, M.A.; Norbertczak, H.; Walker, D.; Simmonds, M.; et al. Pseudogene accumulation in the evolutionary histories of Salmonella enterica serovars Paratyphi A and Typhi. BMC Genom. 2009, 10, 36. [CrossRef]

101. Thomson, N.R.; Clayton, D.J.; Windhorst, D.; Vernikos, G.; Davidson, S.; Churcher, C.; Quail, M.A.; Stevens, M.; Jones, M.A.; Watson, M.; et al. Comparative genome analysis of Salmonella Enteritidis PT4 and Salmonella Gallinarum 287/91 provides insights into evolutionary and host adaptation pathways. Genome Res. 2008, 18, 1624-1637. [CrossRef] 
102. Ochman, H.; Groisman, E.A. Distribution of pathogenicity islands in Salmonella spp. Infect. Immun. 1996, 64, 5410-5412. [CrossRef] [PubMed]

103. Lemire, S.; Figueroa-Bossi, N.; Bossi, L. A singular case of prophage complementation in mutational activation of recET orthologs in Salmonella enterica serovar Typhimurium. J. Bacteriol. 2008, 190, 6857-6866. [CrossRef]

104. Helmuth, R.; Stephan, R.; Bunge, C.; Hoog, B.; Steinbeck, A.; Bulling, E. Epidemiology of virulence-associated plasmids and outer membrane protein patterns within seven common Salmonella serotypes. Infect. Immun. 1985, 48, 175-182. [CrossRef] [PubMed]

105. Tsui, I.S.; Yip, C.M.; Hackett, J.; Morris, C. The type IVB pili of Salmonella enterica serovar Typhi bind to the cystic fibrosis transmembrane conductance regulator. Infect. Immun. 2003, 71, 6049-6050. [CrossRef] [PubMed]

106. Fuentes, J.A.; Villagra, N.; Castillo-Ruiz, M.; Mora, G.C. The Salmonella Typhi hlyE gene plays a role in invasion of cultured epithelial cells and its functional transfer to S. Typhimurium promotes deep organ infection in mice. Res. Microbiol. 2008, 159, 279-287. [CrossRef] [PubMed]

107. Fowler, C.C.; Chang, S.J.; Gao, X.; Geiger, T.; Stack, G.; Galán, J.E. Emerging insights into the biology of typhoid toxin. Curr. Opin. Microbiol. 2017, 35, 70-77. [CrossRef]

108. Song, J.; Gao, X.; Galán, J.E. Structure and function of the Salmonella Typhi chimaeric A(2)B(5) typhoid toxin. Nature 2013, 499, 350-354. [CrossRef]

109. de Jong, H.K.; Parry, C.M.; van der Poll, T.; Wiersinga, W.J. Host-pathogen interaction in invasive Salmonellosis. PLoS Pathog. 2012, 8, e1002933. [CrossRef]

110. Garai, P.; Gnanadhas, D.P.; Chakravortty, D. Salmonella enterica serovars Typhimurium and Typhi as model organisms: Revealing paradigm of host-pathogen interactions. Virulence 2012, 3, 377-388. [CrossRef]

111. Levine, M.M.; Tacket, C.O.; Sztein, M.B. Host-Salmonella interaction: Human trials. Microbes Infect. 2001, 3, 1271-1279. [CrossRef]

112. Jepson, M.A.; Clark, M.A. The role of M cells in Salmonella infection. Microbes Infect. 2001, 3, 1183-1190. [CrossRef]

113. Forrest, B.D.; LaBrooy, J.T.; Beyer, L.; Dearlove, C.E.; Shearman, D.J. The human humoral immune response to Salmonella typhi Ty21a. J. Infect. Dis. 1991, 163, 336-345. [CrossRef] [PubMed]

114. Tagliabue, A.; Nencioni, L.; Caffarena, A.; Villa, L.; Boraschi, D.; Cazzola, G.; Cavalieri, S. Cellular immunity against Salmonella typhi after live oral vaccine. Clin. Exp. Immunol. 1985, 62, 242-247. [PubMed]

115. Perez-Lopez, A.; Behnsen, J.; Nuccio, S.P.; Raffatellu, M. Mucosal immunity to pathogenic intestinal bacteria. Nat. Rev. Immunol. 2016, 16, 135-148. [CrossRef]

116. Hayashi, F.; Smith, K.D.; Ozinsky, A.; Hawn, T.R.; Yi, E.C.; Goodlett, D.R.; Eng, J.K.; Akira, S.; Underhill, D.M.; Aderem, A. The innate immune response to bacterial flagellin is mediated by Toll-like receptor 5. Nature 2001, 410, 1099-1103. [CrossRef]

117. Tötemeyer, S.; Kaiser, P.; Maskell, D.J.; Bryant, C.E. Sublethal infection of C57BL/6 mice with Salmonella enterica Serovar Typhimurium leads to an increase in levels of Toll-like receptor 1 (TLR1), TLR2, and TLR9 mRNA as well as a decrease in levels of TLR6 mRNA in infected organs. Infect. Immun. 2005, 73, 1873-1878. [CrossRef] [PubMed]

118. Wangdi, T.; Lee, C.Y.; Spees, A.M.; Yu, C.; Kingsbury, D.D.; Winter, S.E.; Hastey, C.J.; Wilson, R.P.; Heinrich, V.; Bäumler, A.J. The Vi capsular polysaccharide enables Salmonella enterica serovar typhi to evade microbe-guided neutrophil chemotaxis. PLoS Pathog. 2014, 10, e1004306. [CrossRef] [PubMed]

119. Weiss, D.S.; Raupach, B.; Takeda, K.; Akira, S.; Zychlinsky, A. Toll-like receptors are temporally involved in host defense. J. Immunol. 2004, 172, 4463-44639. [CrossRef]

120. Pier, G.B.; Grout, M.; Zaidi, T.; Meluleni, G.; Mueschenborn, S.S.; Banting, G.; Ratcliff, R.; Evans, M.J.; Colledge, W.H. Salmonella typhi uses CFTR to enter intestinal epithelial cells. Nature 1998, 393, 79-82. [CrossRef]

121. Dougan, G.; Baker, S. Salmonella enterica serovar Typhi and the pathogenesis of typhoid fever. Annu. Rev. Microbiol. 2014, 68, 317-336. [CrossRef]

122. Raffatellu, M.; Chessa, D.; Wilson, R.P.; Dusold, R.; Rubino, S.; Bäumler, A.J. The Vi capsular antigen of Salmonella enterica serotype Typhi reduces Toll-like receptor-dependent interleukin-8 expression in the intestinal mucosa. Infect. Immun. 2005, 73, 3367-3374. [CrossRef]

123. Lee, S.; Yang, Y.A.; Milano, S.K.; Nguyen, T.; Ahn, C.; Sim, J.H.; Thompson, A.J.; Hillpot, E.C.; Yoo, G.; Paulson, J.C.; et al Salmonella Typhoid Toxin PltB Subunit and Its Non-typhoidal Salmonella Ortholog Confer Differential Host Adaptation and Virulence. Cell Host Microbe 2020, 27, 937-949.e6. [CrossRef]

124. Yang, Y.A.; Lee, S.; Zhao, J.; Thompson, A.J.; McBride, R.; Tsogtbaatar, B.; Paulson, J.C.; Nussinov, R.; Deng, L.; Song, J. In vivo tropism of Salmonella Typhi toxin to cells expressing a multiantennal glycan receptor. Nat. Microbiol. 2018, 3, 155-163. [CrossRef] [PubMed]

125. Hornick, R.B.; Greisman, S.E.; Woodward, T.E.; DuPont, H.L.; Dawkins, A.T.; Snyder, M.J. Typhoid fever: Pathogenesis and immunologic control. N. Engl. J. Med. 1970, 283, 686-691. [CrossRef]

126. Hiyoshi, H.; Wangdi, T.; Lock, G.; Saechao, C.; Raffatellu, M.; Cobb, B.A.; Bäumler, A.J. Mechanisms to Evade the Phagocyte Respiratory Burst Arose by Convergent Evolution in Typhoidal Salmonella Serovars. Cell Rep. 2018, 22, 1787-1797. [CrossRef] [PubMed]

127. Storey, H.L.; Huang, Y.; Crudder, C.; Golden, A.; de los Santos, T.; Hawkins, K. A Meta-Analysis of Typhoid Diagnostic Accuracy Studies: A Recommendation to Adopt a Standardized Composite Reference. PLoS ONE 2015, 10, e0142364. [CrossRef] [PubMed] 
128. Helman, S.K.; Mummah, R.O.; Gostic, K.M.; Buhnerkempe, M.G.; Prager, K.C.; Lloyd-Smith, J.O. Estimating prevalence and test accuracy in disease ecology: How Bayesian latent class analysis can boost or bias imperfect test results. Ecol. Evol. 2020, 10, 7221-7232. [CrossRef] [PubMed]

129. Islam, K.; Sayeed, M.A.; Hossen, E.; Khanam, F.; Charles, R.C.; Andrews, J.; Ryan, E.T.; Qadri, F. Comparison of the Performance of the TPTest, Tubex, Typhidot and Widal Immunodiagnostic Assays and Blood Cultures in Detecting Patients with Typhoid Fever in Bangladesh, Including Using a Bayesian Latent Class Modeling Approach. PLoS Negl. Trop. Dis. 2016, 10, e0004558. [CrossRef] [PubMed]

130. Arora, P.; Thorlund, K.; Brenner, D.R.; Andrews, R.J. Comparative accuracy of typhoid diagnostic tools: A Bayesian latent-class network analysis. PLoS Negl. Trop. Dis. 2019, 13, e0007303. [CrossRef]

131. Moore, C.E.; Pan-Ngum, W.; Wijedoru, L.P.M.; Sona, S.; Nga, T.V.T.; Duy, P.T.; Vinh, P.V.; Chheng, K.; Kumar, V.; Emary, K.; et al. Evaluation of the diagnostic accuracy of a typhoid IgM flow assay for the diagnosis of typhoid fever in Cambodian children using a Bayesian latent class model assuming an imperfect gold standard. Am. J. Trop. Med. Hyg. 2014, 90, 114-120. [CrossRef]

132. Liang, L.; Juarez, S.; Nga, T.V.; Dunstan, S.; Nakajima-Sasaki, R.; Davies, D.H.; McSorley, S.; Baker, S.; Felgner, P.L. Immune profiling with a Salmonella Typhi antigen microarray identifies new diagnostic biomarkers of human typhoid. Sci. Rep. 2013, 3, 1043. [CrossRef] [PubMed]

133. Charles, R.C.; Liang, L.; Khanam, F.; Sayeed, M.A.; Hung, C.; Leung, D.T.; Baker, S.; Ludwig, A.; Harris, J.B.; Larocque, R.C.; et al. Immunoproteomic analysis of antibody in lymphocyte supernatant in patients with typhoid fever in Bangladesh. Clin. Vaccine Immunol. 2014, 21, 280-285. [CrossRef] [PubMed]

134. Darton, T.C.; Baker, S.; Randall, A.; Dongol, S.; Karkey, A.; Voysey, M.; Carter, M.J.; Jones, C.; Trappl, K.; Pablo, J.; et al. Identification of Novel Serodiagnostic Signatures of Typhoid Fever Using a Salmonella Proteome Array. Front. Microbiol. 2017, 8, 1794. [CrossRef] [PubMed]

135. Charles, R.C.; Sheikh, A.; Krastins, B.; Harris, J.B.; Bhuiyan, M.S.; LaRocque, R.C.; Logvinenko, T.; Sarracino, D.A.; Kudva, I.T.; Eisenstein, J.; et al. Characterization of anti-Salmonella enterica serotype Typhi antibody responses in bacteremic Bangladeshi patients by an immunoaffinity proteomics-based technology. Clin. Vaccine Immunol. 2010, 17, 1188-1195. [CrossRef]

136. Ansong, C.; Yoon, H.; Norbeck, A.D.; Gustin, J.K.; McDermott, J.E.; Mottaz, H.M.; Rue, J.; Adkins, J.N.; Heffron, F.; Smith, R.D. Proteomics analysis of the causative agent of typhoid fever. J. Proteome Res. 2008, 7, 546-557. [CrossRef]

137. Yang, Y.A.; Chong, A.; Song, J. Why Is Eradicating Typhoid Fever So Challenging: Implications for Vaccine and Therapeutic Design. Vaccines 2018, 6, 45. [CrossRef]

138. Johnson, R.; Mylona, E.; Frankel, G. Typhoidal Salmonella: Distinctive virulence factors and pathogenesis. Cell Microbiol. 2018, 20, e12939. [CrossRef] [PubMed]

139. Harris, J.B.; Baresch-Bernal, A.; Rollins, S.M.; Alam, A.; LaRocque, R.C.; Bikowski, M.; Peppercorn, A.F.; Handfield, M.; Hillman, J.D.; Qadri, F.; et al. Identification of in vivo-induced bacterial protein antigens during human infection with Salmonella enterica serovar Typhi. Infect. Immun. 2006, 74, 5161-5168. [CrossRef]

140. Park, K.S.; Chung, H.J.; Khanam, F.; Lee, H.; Rashu, R.; Bhuiyan, M.T.; Berger, A.; Harris, J.B.; Calderwood, S.B.; Ryan, E.T.; et al. A magneto-DNA nanoparticle system for the rapid and sensitive diagnosis of enteric fever. Sci. Rep. 2016, 6, 32878. [CrossRef]

141. Kirkpatrick, B.D.; Bentley, M.D.; Thern, A.M.; Larsson, C.J.; Ventrone, C.; Sreenivasan, M.V.; Bourgeois, L. Comparison of the antibodies in lymphocyte supernatant and antibody-secreting cell assays for measuring intestinal mucosal immune response to a novel oral typhoid vaccine (M01ZH09). Clin. Diagn. Lab. Immunol. 2005, 12, 1127-1129. [CrossRef]

142. Sheikh, A.; Bhuiyan, M.S.; Khanam, F.; Chowdhury, F.; Saha, A.; Ahmed, D.; Jamil, K.M.; LaRocque, R.C.; Harris, J.B.; Ahmad, M.M.; et al. Salmonella enterica serovar Typhi-specific immunoglobulin A antibody responses in plasma and antibody in lymphocyte supernatant specimens in Bangladeshi patients with suspected typhoid fever. Clin. Vaccine Immunol. 2009, 16, 1587-1594. [CrossRef]

143. von Rhein, C.; Hunfeld, K.P.; Ludwig, A. Serologic evidence for effective production of cytolysin a in salmonella enterica serovars typhi and paratyphi a during human infection. Infect. Immun. 2006, 74, 6505-6508. [CrossRef] [PubMed]

144. Andrews, J.R.; Khanam, F.; Rahman, N.; Hossain, M.; Bogoch, I.I.; Vaidya, K.; Kelly, M.; Calderwood, S.B.; Bhuiyan, T.R.; Ryan, E.T.; et al. Plasma Immunoglobulin A Responses Against 2 Salmonella Typhi Antigens Identify Patients with Typhoid Fever. Clin. Infect. Dis. 2019, 68, 949-955. [CrossRef] [PubMed]

145. Davies, D.H.; Jain, A.; Nakajima, R.; Liang, L.; Jasinskis, A.; Supnet, M.; Felgner, P.L.; Teng, A.; Pablo, J.; Molina, D.M.; et al. Serodiagnosis of Acute Typhoid Fever in Nigerian Pediatric Cases by Detection of Serum IgA and IgG Against Hemolysin E and Lipopolysaccharide. Am. J. Trop. Med. Hyg. 2016, 95, 431-439. [CrossRef] [PubMed]

146. Ong, E.B.; Ignatius, J.; Anthony, A.A.; Aziah, I.; Ismail, A.; Lim, T.S. Multi-isotype antibody responses against the multimeric salmonella typhi recombinant hemolysin e antigen. Multi-isotype antibody responses against the multimeric Salmonella Typhi recombinant hemolysin E antigen. Microbiol. Immunol. 2015, 59, 43-47. [CrossRef]

147. Felgner, J.; Jain, A.; Nakajima, R.; Liang, L.; Jasinskas, A.; Gotuzzo, E.; Vinetz, J.M.; Miyajima, F.; Pirmohamed, M.; Hassan-Hanga, F.; et al. Development of ELISAs for diagnosis of acute typhoid fever in Nigerian children. PLoS Negl. Trop. Dis. 2017, 11, e0005679. [CrossRef] [PubMed]

148. Franklin, F.; Chong, C.W.; Chua, L.H.; Anthony, A.A.; Liew, M.W.O.; Aziah, I.; Ong, E.B.B. Evaluation of Salmonella Typhi antigen YncE alongside HlyE for the detection of typhoid fever and its carriers. Med. Microbiol. Immunol. 2020, 209, 593-601. [CrossRef] [PubMed] 
149. Chin, K.L.; Redhuan, N.E.; Balaram, P.; Phua, K.K.; Ong, E.B. Detection of Salivary IgA Antibodies Against the HlyE Antigen as a Diagnosis of Typhoid Fever. J. Clin. Diagn. Res. 2016, 10, Dm01-Dm03. [CrossRef]

150. Kumar, S.; Nodoushani, A.; Khanam, F.; DeCruz, A.T.; Lambotte, P.; Scott, R.; Bogoch, I.I.; Vaidya, K.; Calderwood, S.B.; Bhuiyan, T.R.; et al. Evaluation of a Rapid Point-of-Care Multiplex Immunochromatographic Assay for the Diagnosis of Enteric Fever. mSphere 2020, 5. [CrossRef]

151. Sharma, T.; Sharma, C.; Sankhyan, A.; Bedi, S.P.; Bhatnagar, S.; Khanna, N.; Gautam, V.; Sethi, S.; Vrati, S.; Tiwari, A. Serodiagnostic evaluation of recombinant CdtB of S. Typhi as a potential candidate for acute typhoid. Immunol. Res. 2018, 66, 503-512. [CrossRef]

152. Tran Vu Thieu, N.; Van, T.T.; Tuan, A.T.; Klemm, E.J.; Minh, C.N.N.; Vinh, P.V.; Thanh, D.P.; Dan, T.H.N.; Duc, T.P.; Langat, P.; et al. An evaluation of purified Salmonella Typhi protein antigens for the serological diagnosis of acute typhoid fever. J. Infect. 2017, 75, 104-114. [CrossRef]

153. Khanam, F.; Sheikh, A.; Sayeed, M.A.; Bhuiyan, M.S.; Choudhury, F.K.; Salma, U.; Pervin, S.; Sultana, T.; Ahmed, D.; Goswami, D.; et al. Evaluation of a typhoid/paratyphoid diagnostic assay (TPTest) detecting anti-Salmonella IgA in secretions of peripheral blood lymphocytes in patients in Dhaka, Bangladesh. PLoS Negl. Trop. Dis. 2013, 7, e2316. [CrossRef] [PubMed]

154. Sheikh, A.; Charles, R.C.; Sharmeen, N.; Rollins, S.M.; Harris, J.B.; Bhuiyan, M.S.; Arifuzzaman, M.; Khanam, F.; Bukka, A.; Kalsy, A.; et al. In vivo expression of Salmonella enterica serotype Typhi genes in the blood of patients with typhoid fever in Bangladesh. PLoS Negl. Trop. Dis. 2011, 5, e1419. [CrossRef] [PubMed]

155. Thompson, L.J.; Dunstan, S.J.; Dolecek, C.; Perkins, T.; House, D.; Dougan, G.; Nguyen, T.H.; Tran, T.P.; Doan, C.D.; Le, T.P.; et al. Transcriptional response in the peripheral blood of patients infected with Salmonella enterica serovar Typhi. Proc. Natl. Acad. Sci. USA 2009, 106, 22433-22438. [CrossRef] [PubMed]

156. Blohmke, C.J.; Muller, J.; Gibani, M.M.; Dobinson, H.; Shrestha, S.; Perinparajah, S.; Jin, C.; Hughes, H.; Blackwell, L.; Dongol, S.; et al. Diagnostic host gene signature for distinguishing enteric fever from other febrile diseases. EMBO Mol. Med. 2019, 11, e10431. [CrossRef] [PubMed]

157. Näsström, E.; Thieu, N.T.V.; Dongol, S.; Karkey, A.; Vinh, P.V.; Thanh, T.H.; Johansson, A.; Arjyal, A.; Thwaites, G.; Dolecek, C.; et al. Salmonella Typhi and Salmonella Paratyphi A elaborate distinct systemic metabolite signatures during enteric fever. eLife 2014, 3. [CrossRef]

158. Darton, T.C.; Blohmke, C.J.; Giannoulatou, E.; Waddington, C.S.; Jones, C.; Sturges, P.; Webster, C.; Drakesmith, H.; Pollard, A.J.; Armitage, A.E. Rapidly Escalating Hepcidin and Associated Serum Iron Starvation Are Features of the Acute Response to Typhoid Infection in Humans. PLoS Negl. Trop. Dis. 2015, 9, e0004029. [CrossRef] [PubMed]

159. Blohmke, C.J.; Darton, T.C.; Jones, C.; Suarez, N.M.; Waddington, C.S.; Angus, B.; Zhou, L.; Hill, J.; Clare, S.; Kane, L.; et al. Interferon-driven alterations of the host's amino acid metabolism in the pathogenesis of typhoid fever. J. Exp. Med. 2016, 213, 1061-1077. [CrossRef] 